\title{
Rabies infection and specific effect of vaccination in mice selected for high and low immunobiological parameters
}

L.H. Queiroz-da-Silva ${ }^{1}$,

M. De-Franco ${ }^{2}$ and

O.A. Sant'Anna ${ }^{2}$
${ }^{1}$ Departamento de Apoio, Produção e Saúde Animal, Curso de Medicina Veterinária, Universidade Estadual Paulista, Araçatuba, SP, Brasil

${ }^{2}$ Laboratório de Imunogenética, Instituto Butantan, São Paulo, SP, Brasil

\section{Correspondence \\ L.H. Queiroz-da-Silva \\ Departamento de Apoio, Produção e Saúde Animal \\ Curso de Medicina Veterinária UNESP \\ Caixa Postal 533 \\ 16050-680 Araçatuba, SP \\ Brasil}

O.A. Sant'Anna and M. De-Franco were supported in part by CNPq. Publication supported by FAPESP.

Received October 18, 1996 Accepted September 25, 1997

\begin{abstract}
Innate and acquired resistance to rabies infection was investigated in mice genetically selected for high $(\mathrm{H})$ or low $(\mathrm{L})$ antibody responsiveness from selections I, III and IV and in mice selected for maximal (AIRmax) or minimal (AIRmin) acute inflammatory reaction. These mouse lines were infected intramuscularly with different virus dilutions and the $\mathrm{LD}_{50}$ was determined. The HIII and HIV mouse lines were more susceptible than the LIII and LIV lines and the HI line showed a discrete but higher resistance than the LI line. Analysis of the interline ( $\mathrm{H} \times \mathrm{L}$ ) $\mathrm{F} 1$ hybrids from selections III and IV indicated different dominance effects on the "resistant" and "susceptible" phenotypes when the route of vaccination was changed. No differences were observed between the AIRmax and AIRmin mice, suggesting that inflammation plays a minor role in the resistance to rabies virus. The comparison of $\mathrm{LD}_{50}$ in mice vaccinated by distinct routes showed that the highest interline difference occurred after intramuscular vaccination (250-fold between $\mathrm{H}$ and $\mathrm{L}$ and 800 -fold between $\mathrm{F} 1$ and $\mathrm{L}$ ). These results indicate that different mechanisms may participate in acquired antirabies resistance.
\end{abstract}

Key words

- Rabies

- Antibody

- Vaccination

- High and low antibody responder mice
Rabies is a viral disease caused by a rhabdovirus which has been known for many centuries. Experimental infections in mice have been developed after their susceptibility to rabies virus was demonstrated, with different levels of mortality (1). Several experiments have been carried out to study the susceptibility and resistance of mice to rabies infection (2) and isogenic mice have been used to demonstrate that resistance to rabies virus infection is genetically controlled by at least two genes $(3,4)$. The resistance to rabies virus was positively correlated with serum neutralizing antibody in two distinct mouse models, i.e., inbred (5) and genetically selected (6) hyper- and hyporesponder mice.

Investigation of the genes controlling antibody production against rabies virus was recently approached in genetically selected mice, showing that 3 independent loci were involved (7). Production of these lines endowed with maximal or minimal antibody response and inflammatory reaction traits by selective breeding has proved to be useful in studies of host-infection interactions.

In the present study, we used mice selected for high $(\mathrm{H})$ and low $(\mathrm{L})$ antibody 
response to erythrocytes (selection I), flagellar (selection III) and somatic (selection IV) Salmonella antigens (8) and for maximal (AIRmax) or minimal (AIRmin) acute inflammatory reaction to polyacrylamide beads (9) in order to investigate the eventual participation of innate and/or acquired resistance to rabies virus using different vaccination routes. It was observed that $\mathrm{L}$ mouse lines from selections III and IV were more resistant than $\mathrm{H}$ mice. However, $\mathrm{H}$ mice were more resistant than $\mathrm{L}$ mice when previous vaccination was performed. F1 hybrids showed distinct dominance effects.

Genetically selected mice from selections I, III and IV and their ( $\mathrm{H} \times \mathrm{L}) \mathrm{F} 1$ hybrids and from AIR selection, aged 2-4 months, were used. Swiss albino mice, aged 21 days (11$14 \mathrm{~g}$ ), from the outbred colony of the Instituto Biológico (São Paulo) were used for stan-

Table 1 - Fifty percent lethal dose (LD 50 ) of rabies virus (CVS strain) in nonvaccinated mice inoculated intramuscularly.

Mice were infected with $10^{-2}$ to $10^{-5}$ virus dilution in a volume of $0.2 \mathrm{ml}$ and observed for 21 days for clinical symptoms and mortality. $d / a=$ Dominance effect; $d=$ global dominance; $a$ = additive effect. n.s., Nonsignificant.

\begin{tabular}{|c|c|c|c|c|c|}
\hline Selections & Line & No. of animals & $-\log L D_{5} / \mathrm{ml}$ & $P$ & $d / a$ \\
\hline \multirow[t]{4}{*}{ । } & $\mathrm{H}$ & 12 & $3.3 \pm 0.20$ & & \\
\hline & & & & $>0.02<0.05$ & -1.00 \\
\hline & L & 12 & $3.5 \pm 0.24$ & & \\
\hline & F1 & 12 & $3.5 \pm 0.23$ & & \\
\hline \multirow[t]{4}{*}{ III } & $\mathrm{H}$ & 16 & $4.2 \pm 0.16$ & & \\
\hline & & & & $<0.001$ & -1.33 \\
\hline & L & 16 & $3.6 \pm 0.23$ & & \\
\hline & F1 & 10 & $3.5 \pm 0.20$ & & \\
\hline \multirow[t]{4}{*}{ IV } & $\mathrm{H}$ & 12 & $4.0 \pm 0.24$ & & \\
\hline & & & & $<0.001$ & 0 \\
\hline & L & 11 & $3.4 \pm 0.25$ & & \\
\hline & $\mathrm{F} 1$ & 10 & $3.7 \pm 0.24$ & & \\
\hline \multirow[t]{3}{*}{ AIR } & AlRmax & 5 & $3.7 \pm 0.40$ & & \\
\hline & & & & n.s. & \\
\hline & AlRmin & 5 & $3.4 \pm 0.30$ & & \\
\hline
\end{tabular}

dard virus titration.

Stock virus of the CVS (challenge virus standard) strain of rabies virus maintained by passage in suckling mice was used with a titer of $10^{7.5}$ mouse intracerebral $50 \%$ lethal doses $\left(\mathrm{MICLD}_{50}\right)$ in $0.03 \mathrm{ml}$, as calculated by the method of Reed and Muench (10).

Mice were infected intramuscularly $(\mathrm{im})$ with $10^{-2}$ to $10^{-5}$ virus dilutions in a volume of $0.2 \mathrm{ml}(0.1 \mathrm{ml}$ in each leg) and observed for 21 days. During this time clinical symptoms and mortality were recorded daily. Groups of 5 to 16 mice were used for each dilution and the MICLD ${ }_{50}$ were obtained by the method of Reed and Muench (10).

Three groups of 16 to 18 mice of the HIII and LIII lines and their F1 hybrids received two injections of $0.5 \%$ suckling mouse brain Fuenzalida and Palacios (11) rabies vaccine containing $0.6 \mathrm{IU} / \mathrm{ml}, 2$ days apart, by the intraperitoneal (ip), $\mathrm{im}$ and subcutaneous $(s c)$ routes. Fourteen days after the first injection each group was challenged intracerebrally with $0.03 \mathrm{ml}$ of CVS diluted $10^{-2}$ to $10^{-4}$ for $\mathrm{H}$ mice and $\mathrm{F} 1$ hybrids and $10^{-4}$ to $10^{-7}$ for L mice. Groups of 6 non-vaccinated mice from the same mouse lines received $10^{-5}$ to $10^{-7}$ virus dilution in a volume of $0.03 \mathrm{ml}$ intracerebrally. All animals were observed for 21 days and mortality was recorded.

The standard error of the $50 \%$ lethal doses $\left(\mathrm{LD}_{50}\right)$ was determined by Pizzi's formula as described in Ref. 12 based on the number of dead mice for each virus dilution and the Student $t$-test was used to show the significance of difference in $\mathrm{LD}_{50}$ at $\mathrm{P}<0.05$. The dominance effect is reported as the $d / a$ ratio, where $a$ is the additive effect $\left(a=\mathrm{LD}_{50} \mathrm{H}\right.$ $\left.\mathrm{LD}_{50} \mathrm{~L} / 2\right)$ and $d$ is the global dominance $(d=$ $\left.\mathrm{LD}_{50} \mathrm{~F} 1-\left[\mathrm{LD}_{50} \mathrm{H}+\mathrm{LD}_{50} \mathrm{~L} / 2\right]\right)$.

Innate resistance was investigated in the $\mathrm{H}$ and $\mathrm{L}$ mice and in their $\mathrm{F} 1$ hybrids from selections I, III and IV as well as in AIRmax and AIRmin mice, and the $\mathrm{LD}_{50}$ for CVS strain rabies virus inoculated im was determined. The results of $\mathrm{LD}_{50}$, their standard error and the dominance effect are shown in 


\begin{tabular}{|c|c|c|c|c|c|}
\hline \multicolumn{6}{|c|}{$\begin{array}{l}\text { Mice received two vaccine injections } 2 \text { days apart and were challenged } 12 \text { days after the } \\
\text { second immunization by the intracerebral route. The number of mice in each group was } \\
\text { 18. The protective index is the antilog of subtraction of the } L D_{50} / 0.03 \mathrm{ml} \text { values for } \\
\text { control and vaccinated mice. n.s., Nonsignificant. }\end{array}$} \\
\hline \multirow{2}{*}{ Vaccination route } & \multirow{2}{*}{ Line } & \multicolumn{2}{|c|}{$L_{50}(-\log 10)$} & \multirow{2}{*}{ Protective index } & \multirow{2}{*}{$\mathrm{P}$} \\
\hline & & Non-vaccinated & Vaccinated & & \\
\hline \multirow[t]{3}{*}{ Intraperitoneal } & HIII & $6.2 \pm 0.4$ & $2.5 \pm 0.5$ & 5000 & $<0.001$ \\
\hline & LIII & $6.5 \pm 0.3$ & $4.7 \pm 0.4$ & 63 & $<0.001$ \\
\hline & $\mathrm{F} 1$ & $6.2 \pm 0.3$ & $3.5 \pm 0.3$ & 500 & $<0.001$ \\
\hline \multirow[t]{3}{*}{ Intramuscular } & HIII & $6.2 \pm 0.4$ & $3.5 \pm 0.3$ & 500 & $<0.001$ \\
\hline & LIII & $6.5 \pm 0.3$ & $6.2 \pm 0.3$ & 2 & n.s. \\
\hline & $\mathrm{F} 1$ & $6.2 \pm 0.3$ & $3.0 \pm 0.6$ & 1600 & $<0.001$ \\
\hline \multirow[t]{3}{*}{ Subcutaneous } & HIII & $6.2 \pm 0.4$ & $3.5 \pm 0.3$ & 500 & $<0.001$ \\
\hline & LIII & $6.5 \pm 0.3$ & $5.3 \pm 0.4$ & 16 & $<0.001$ \\
\hline & $\mathrm{F} 1$ & $6.2 \pm 0.3$ & $5.2 \pm 0.5$ & 10 & $<0.001$ \\
\hline
\end{tabular}

Table 1. LIII and LIV mice were more resistant than HIII and HIV mice $(\mathrm{P}<0.001)$ and the interline differences were discrete for selection I $(0.02<\mathrm{P}<0.05)$ or absent for selection AIR. A complete dominance of the susceptibility trait in F1 hybrids from selection I, overdominance of the resistance trait in selection III and codominance in selection IV were noted.

Considering the antibody production and its importance for the modulation of innate resistance, the results observed in selection I were in accordance with those obtained by Consales et al. (13) and Nilsson et al. (6). The $\mathrm{H}$ and $\mathrm{L}$ antibody responder mice differed widely in basal serum immunoglobulin concentration with significantly higher levels of IgM, IgA, IgG3, IgG1, IgG2b and $\mathrm{IgG} 2 \mathrm{a}$ isotypes in $\mathrm{H}$ than in $\mathrm{L}$ mice (14). The same pattern of differences was observed in the isotype distribution against flagellar and somatic Salmonella antigens, which were the selection immunogens for $\mathrm{H}$ and $\mathrm{L}$ mouse lines from selections III and IV, respectively. That pattern was also observed for the isotype distribution of antibody responses to heterologous erythrocytes in $\mathrm{H}$ and $\mathrm{L}$ mice from selection I developed for responsiveness to this immunogen (15).

These data suggest that there were no restrictions in isotype or epitope recognition in these selections, although it should be considered that macrophages have a higher catabolic activity in LI than in HI mice, a fact that would determine differences between these lines (16). In selections III and IV, there was no difference in the catabolic activity of macrophages, and therefore the higher resistance of $L$ mice may be explained by intrinsic genetic factors. In these mice a larger number of virus receptors have probably accumulated by genetic drift, in the same manner as determined for heparin (17) and MMTV integration (18).

In the AIR selection, where mice differ only in acute inflammatory responsiveness but not in antibody production (Ribeiro OG, personal communication), there was no difference in the sensitivity to rabies virus, suggesting a small participation of neutrophils and local inflammatory proteins in innate resistance to rabies.

Table 2 shows the $\mathrm{LD}_{50}$ values for both vaccinated and non-vaccinated intracere- 
brally challenged groups of mice from selection III and the protective index (pi) calculated by the difference between them. In mice vaccinated $i p$, a significant difference $(\mathrm{P}<0.001)$ was observed between $\mathrm{H}$ and $\mathrm{L}$ mice (80-fold), $\mathrm{H}$ and F1 (10-fold) and between F1 and L mice (8-fold) in relation to the protective index. L mice did not present any protection when vaccinated $\mathrm{im}$; therefore, this route gave the maximal interline separation with a highly significant difference $(\mathrm{P}<0.001)$ between $\mathrm{H}$ and $\mathrm{L}$ ( 250 -fold) and between F1 and L (800-fold). The lowest interline difference in protective index was observed for subcutaneous vaccination with a statistically significant $(\mathrm{P}<0.001)$ difference between $\mathrm{H}$ and $\mathrm{L}$ (32-fold) and between $\mathrm{H}$ and $\mathrm{F} 1$ mice (50-fold) but almost no difference was observed between $\mathrm{L}$ and $\mathrm{F} 1$ (1.6-fold).

These results indicate that the intraperitoneal route was the most immunogenic, probably due to the ip protocol employed during the selective process (8). In this case, the selective pressure may have been expressed at the presenting cell level and/or at the level of their interactions with effector lymphocytes, as seen for other antigens (16).

When vaccination was performed by the intraperitoneal and intramuscular route, F1 hybrids from selection III showed a behavior similar to that observed for HIII mice, while after subcutaneous vaccination, the $\mathrm{LD}_{50}$ was similar to that obtained for L mice with a low but significant protective index.

The higher interline difference was ob- tained after vaccination by the intramuscular route, since LIII mice did not show any response to the vaccine $(\mathrm{pi}=2)$. $\mathrm{F} 1$ hybrids were more resistant than $\mathrm{H}$ mice after challenge with the CVS strain (pi =1,600). On the basis of the $\mathrm{LD}_{50}$ results for $\mathrm{F} 1$ hybrids, it could be observed that there were distinct dominance effects on the "resistant" or "susceptible" phenotypes which changed according to the route of inoculation, suggesting the relevance of enviromental factors for the expression of these traits.

The present results suggest that the innate and acquired resistance against rabies virus involves genetic traits other than antibody responsiveness or inflammatory aptness. In spite of the importance of the humoral response (7), we cannot exclude differences at the cellular level such as the effector role of macrophages, interferons and specific T lymphocytes in this infection. Thus, future investigations of these factors using the genetically selected mouse model will be important to determine host-infection interactions and some aspects of immunotherapy and vaccination efficacy.

\section{Acknowledgments}

The authors are indebted to the staff of the Seção de Raiva e Encefalomielite, Instituto Biológico, São Paulo, for providing facilities during the development of this study, and to Mrs. Elizabeth J.G. Valentini, Instituto Butantan, for providing rabies vaccines. 


\section{References}

1. Johnson HN \& Charles NL (1940). Comparative susceptibility of different strains of mice to rabies virus. American Journal of Hygiene, 32B: 38-45.

2. Baer GM, Cleary WF, Diaz AM \& Perl DF (1977). Characteristics of 11 rabies virus isolates in mice: titers and relative invasiveness of virus, incubation period of infection and survival of mice with sequel. Journal of Infectious Diseases, 136: 336345.

3. Lodmell DL (1983). Genetic control of resistance to street rabies virus in mice. Journal of Experimental Medicine, 157: 451-460.

4. Lodmell DL \& Chesebro B (1984). Murine resistance to street rabies virus: genetic analysis by testing second-backcross progeny and verification of allelic resistance genes in SJL/J and CBA/J mice. Journal of Virology, 50: 359-362.

5. Templeton JW, Holmberg C, Garber T \& Sharp RM (1986). Genetic control of serum neutralizing antibody response to rabies vaccination and survival after a rabies challenge infection in mice. Journal of $\mathrm{Vi}$ rology, 59: 98-102.

6. Nilsson MR, Sant'Anna OA, Siqueira M, Nilsson TT \& Gennari M (1979). Rabies virus immunity in genetically selected high and low responder lines of mice. Infection and Immunity, 25: 23-26.

7. De Franco M, Massa S, Vassão RC, Siqueira M \& Sant'Anna OA (1996). Polygenic control of antibody production and correlation with vaccine induced resistance to rabies virus in high and low antibody responder mice. Archives of Virology, 141: 1397-1406.
8. Siqueira $M$, Bandieri $A$, Reis $M H$, Sant'Anna OA \& Biozzi G (1976). Selective breedings of mice for antibody responsiveness to flagellar and somatic antigens of Salmonellae. European Journal of Immunology, 6: 241-249.

9. Ibanez OM, Stiffel C, Ribeiro OM, Cabrera WK, Massa S, De Franco M, Sant'Anna OA, Decreusefond C, Mouton D, Siqueira M \& Biozzi G (1992). Genetics of nonspecific immunity: I. Bi-directional selective breeding of lines of mice endowed with maximal and minimal inflammatory responsiveness. European Journal of Immunology, 22: 2555-2563.

10. Reed LJ \& Muench H (1938). A simple method of estimating fifty percent endpoints. American Journal of Hygiene, 27: 493-497.

11. Fuenzalida E \& Palacius R (1955). Suckling mouse brain vaccine. Boletin del Instituto Bacteriológico de Chile, 8: 3-10.

12. Schwerdt CE \& Merrel M (1952). Precision of measurement of Lansing virus infectivity in cotton rats. American Journal of Hygiene, 55: 268-275.

13. Consales CA, Mendonça RZ, Luchiari MA, Vassão RC \& Pereira CA (1990). Macrophage activity in rabies virus infection of genetically selected high and low antibody lines of mice. Research Virology, 141: 5767.
14. Sant'Anna OA, Mouton D, Ibanez OM Bouthillier Y, Mevel JC, Reis MH \& Biozzi G (1985). Basal immunoglobulin serum concentration and isotype distribution in relation to the polygenic control of antibody responsiveness in mice. Immunogenetics, 22: 131-139.

15. Sant'Anna OA, Bouthillier $Y$, Mevel JC De Franco M \& Mouton D (1991). Isotypic distribution of antibody responses in lines of mice selected for high and low immunoresponsiveness. Brazilian Journal of Medical and Biological Research, 24: 407416.

16. Biozzi G, Mouton D, Stiffel C \& Bouthillier $Y$ (1984). A major role of the macrophage in quantitative genetic regulation of immunoresponsiveness and anti-infectious immunity. Advances in Immunology, 36: 189-233.

17. Straus $A H$, Sant'Anna OA, Nader HB \& Dietrich CP (1984). An inverse relationship between heparin content and antibody response in genetically selected mice. Biochemical Journal, 220: 625-630.

18. Roger T, Boudaly S \& Seman M (1994) Negative segregation of $M t v$ loci in $\mathrm{H}-2 \mathrm{E}^{+}$ mice selected for high antibody response. Immunogenetics, 40: 123-128. 